None declared., Michael J. Nissen Speakers bureau: AbbVie, Celgene, Eli Lilly and Company, Janssen, Novartis and Pfizer., Consultant of: AbbVie, Celgene, Eli Lilly and Company, Janssen, Novartis and Pfizer., Grant/research support from: AbbVie, Erica Filippi Shareholder of: Eli Lilly and Company, Employee of: Eli Lilly and Company, Hagen Russ Shareholder of: Eli Lilly and Company, Employee of: Eli Lilly and Company, Alper Erdogan Shareholder of: Eli Lilly and Company, Employee of: Eli Lilly and Company, Yves Schymura Employee of: Eli Lilly and Company, Soyi Liu Leage Shareholder of: Eli Lilly and Company, Employee of: Eli Lilly and Company, Eduardo Collantes Estevez Speakers bureau: Novartis, Janssen, Eli Lilly and Company, AbbVie, Paid instructor for: Novartis, Grant/research support from: Eli Lilly and Company, francesco ciccia Speakers bureau: AbbVie, Celgene, UCB, Pfizer, MSD, Amgen, Eli Lilly and Company, Novartis, Sobi, Roche, BMS, Paid instructor for: Novartis, UCB, Pfizer, Consultant of: Novartis, UCB, Pfizer, Grant/research support from: Pfizer, Roche, UCB.

DOI: 10.1136/annrheumdis-2021-eular.1361

\section{AB0466 RETENTION RATE AND EFFECTIVENESS OF SECUKINUMAB VERSUS TNF INHIBITOR SWITCHING IN ANKYLOSING SPONDYLITIS PATIENTS WITH A HISTORY OF TNF INHIBITOR TREATMENT: DATA FROM A KOREAN NATIONWIDE REGISTRY}

H. K. Min ${ }^{1}$, K. Y. Kang ${ }^{2} .{ }^{1}$ Konkuk University Medical Center, Internal Medicine, Seoul, Korea, Republic of (South Korea); ${ }^{2}$ The Catholic University of Korea Incheon St. Mary's Hospital, Internal Medicine, Incheon, Korea, Republic of (South Korea)

Background: The choice of second-line biologics for ankylosing spondylitis (AS) patients previously treated with a tumour necrosis factor inhibitor (TNFi) remains unclear

Objectives: Here, we compared drug retention and clinical efficacy between AS patients who switched biologics to secukinumab and those who switched to a different TNFi.

Methods: AS patients enrolled in the Korean College of Rheumatology BIOlogics registry were included. Patients with previous TNFi exposure were divided into the secukinumab group and the TNFi switching group. Drug retention and clinical efficacy (BASDAI50, ASAS20, ASAS40, ASDAS <2.1, ASDAS clinically important improvement, and ASDAS major improvement) were assessed the 1 year follow-up. Propensity score (PS)-matched and covariate-adjusted logistic regression analyses were performed.

Results: 246 had available 1 year follow-up data. Secukinumab as thirdor later-line biologics was more frequent than alternative TNFi (54\% vs. $14 \%)$. PS-matched and multiple covariate-adjusted analyses showed that the odds ratio $(\mathrm{OR})$ for drug discontinuation was comparable between the secukinumab and TNFi switching groups (OR=1.136; $95 \% \mathrm{Cl}, 0.843-1.531$ and $\mathrm{OR}=1.000 ; 95 \% \mathrm{Cl}, 0.433-2.308$, respectively). The proportion of patients who achieved BASDAI50 was also comparable between the two groups (OR=0.833; 95\% Cl, 0.481-1.441 in PS-matched analysis). Other clinical efficacy parameters were also comparable. In the subgroup analysis of AS patients with previous TNFi discontinuation due to ineffectiveness, all clinical efficacy parameters were comparable between the two groups.

Conclusion: In AS patients with previous exposure to a TNFi, switching biologics to secukinumab and switching to an alternative TNFi resulted in comparable drug retention and clinical efficacy.

REFERENCES:

[1] Micheroli R, Tellenbach C, Scherer A, et al. Effectiveness of secukinumab versus an alternative TNF inhibitor in patients with axial spondyloarthritis previously exposed to TNF inhibitors in the Swiss Clinical Quality Management cohort. Ann Rheum Dis 2020;79:1203-9.

Disclosure of Interests: None declared.

DOI: 10.1136/annrheumdis-2021-eular.1489

\section{AB0467 $\quad$ EFFECTIVENESS OF GOLIMUMAB AFTER T NF-INHIBITOR FAILURE IN PATIENTS WITH ACTIVE RHEUMATOID ARTHRITIS, PSORIATIC ARTHRITIS, OR AXIAL SPONDYLOARTHRITIS: RESULTS AT 3 MONTHS FROM THE GO-BEYOND ITALY STUDY}

S. D'angelo $^{1}$, E. Tirri $^{2}$, A. M. Giardino ${ }^{3}$, M. Matucci-Cerinic ${ }^{4}$, L. Dagna ${ }^{5}$, L. Santo ${ }^{6}$, F. Ciccia ${ }^{7}$, B. Frediani ${ }^{8}$, M. Govoni ${ }^{9}$, F. Bobbio Pallavicini $^{10}$, R. D. Grembiale ${ }^{11}$, A. Delle Sedie ${ }^{12}$, S. Cercone ${ }^{13}$, R. Mule,14, F. P. Cantatore ${ }^{15}$, R. Foti ${ }^{16}, E$. Gremese ${ }^{17}$, R. Perricone ${ }^{18}, F_{\text {. Salaffi }}{ }^{19}$, O. Viapiana ${ }^{20}$, A. Cauli ${ }^{21}$, R. Giacomelli ${ }^{22}$, L. Arcarese ${ }^{23}$, G. Guggino ${ }^{24}$, R. Russo ${ }^{25}$, D. Capocotta ${ }^{26}$,
F. Nacci ${ }^{27}$, M. G. Anelli ${ }^{28}$, V. Picerno ${ }^{29}$, F. lannone ${ }^{30}$ on behalf of GO-BEYOND Italy. ${ }^{1}$ Istituto Reumatologico Lucano (I.Re.L) e Dipartimento Regionale di Reumatologia, AOR San Carlo di Potenza, Potenza, Italy; ${ }^{2}$ Ospedale "San Giovanni Bosco"Napoli, UOSD di Reumatologia, Napoli, Italy; ${ }^{3}$ MSD Italia, Medical Affairs, Rome, Italy; ${ }^{4}$ AOC Careggi, Dipartimento medicina Sperimentale e Clinica, SOD Reumatologia, Firenze, Italy; ${ }^{5}$ IRCCS San Raffaele, San Raffaele University, Scientific Institute \& Vita-Salute, Milan, Italy; ${ }^{6}$ ASL BT - DSS 4 Barletta, U.O.S. Reumatologia, Barletta, Italy; ${ }^{7}$ Università della Campania L. Vanvitelli, Dipartimento di Medicina di precisione, Napoli, Italy; ${ }^{8}$ Policlinico "Le Scotte”, U.O.C. Reumatologia, Siena, Italy; ${ }^{9} \mathrm{AOU}$ S. Anna di Ferrara - University of Ferrara, UOC Reumatologia, Ferrara, Italy; ${ }^{10}$ Fondazione IRCCS Policlinico San Matteo, S.C. di Reumatologia, Pavia, Italy; ${ }^{11}$ University "Magna Græcia, Rheumatology Research Unit, Department of Health Sciences, Catanzaro, Italy; ${ }^{12}$ A.O. Universitaria Pisana, U.O. Reumatologia, Pisa, Italy; ${ }^{13} \mathrm{MSD}$ Italia, Medical Affairs, Roma, Italy; ${ }^{14}$ policlinico Sant'Orsola, Programma dipartimentale di malattie reumatiche, del connettivo e malattie metaboliche dell'osso, Bologna, Italy; ${ }^{15}$ University of Foggia Medical School, Rheumatology Clinic, Department of Medical and Surgical Sciences, Foggia, Italy; ${ }^{16}$ A.O.U. Policlinico S. Marco, U.O di Reumatologia, Catania, Italy; ${ }^{17}$ Fondazione Policlinico Universitario A. Gemelli-IRCCS, Università Cattolica del Sacro Cuore, U.O.C. di Reumatologia, Roma, Italy; ${ }^{18}$ Policlinico Tor Vergata, Dipartimento di Medicina dei Sistemi - UOC Reumatologia, Roma, Italy; ${ }^{19}$ Universita' Politecnica delle Marche, Dipartimento di Scienze Cliniche e Molecolari, Ancona, Italy; ${ }^{20}$ Ospedale Borgo Roma Policlinico G.B. Rossi, U.O.C. Reumatologia, Verona, Italy; ${ }^{21} \mathrm{AOU}$ and University of Cagliari, Rheumatology Unit, Cagliari, Italy; ${ }^{22}$ Campus biomedico di Roma, Immunoreumatologia, Roma, Italy; ${ }^{33}$ Campus Biomedico di Roma, Immunoreumatologia, Roma, Italy; ${ }^{24}$ Università degli Studi di Palermo, Dipartimento PROMISE, Palermo, Italy; ${ }^{25}$ Azienda Ospedaliera RN, A.Cardarelli, U.O.S. Reumatologia, Napoli, Italy; ${ }^{26}$ Ospedale "San Giovanni di Napoli, U.O.S. Dipartimentale di Reumatologia, Napoli, Italy; ${ }^{27}$ AOU Careggi, Dipartimento medicina Sperimentale e Clinica, SOD Reumatologia, Firenze, Italy; ${ }^{28}$ Policlinico, U.O. di Reumatologia Universitaria, Bari, Italy; ${ }^{29}$ Istituto Reumatologico Lucano (I.Re.L), e Dipartimento Regionale di Reumatologia, AOR San Carlo di Potenza, Potenza, Italy; ${ }^{30}$ Policlinico, U.O. di Reumatologia Universitaria, Bari, Italy

Background: Golimumab showed trial efficacy in subjects with active rheumatoid arthritis (RA) previously treated with TNF-inhibitors (TNFi); no tria data are available for psoriatic arthritis (PSA) and axial spondyloarthritis (axSpA).

Objectives: To assess the effectiveness of golimumab after TNFi failure in patients with RA, PsA, or axSpA in a real-world setting.

Methods: GO-BEYOND-Italy is an ongoing, multicenter, prospective, observational study of RA, PsA, or axSpA patients starting golimumab after TNFi failure. Patients were enrolled between July 2017 and December 2019, and followed for 1 year, with evaluations at 3, 6, and 12 months. This interim analysis estimates the effectiveness after 3 months of golimumab therapy. Differences from baseline were tested by paired t-tests.

Results: 193 patients were enrolled: 38 (19.7\%) with RA (median age 54 years; median disease duration 9.5 years), 91 (47.2\%) with PsA (median age 53 years; median disease duration 9.0 years) and $64(33.2 \%)$ with axSpA (median age 54 years; median disease duration 7.2 years). Majority of the RA $(73.7 \%)$, PsA (51.6\%) and axSpA (53.1\%) were females. Previous TNFi treatment included etanercept $(44.6 \%$ of patients), adalimumab $(42.0 \%)$ infliximab (8.8\%) and certolizumab (4.7\%). The main reason for switching to golimumab was loss of efficacy of TNFi $(78.9 \%$ in RA, $83.5 \%$ in PsA, $75 \%$ in axSpA). Comorbidities were highly prevalent (RA 65.8\%, PsA 65.9\%, axSpA $75 \%$ ); hypertension (31.1\%), dyslipidaemia (13.5\%), fibromyalgia (10.4\%) were the most common ones. DAS28-CRP significantly reduced in RA and PsA $(p<0.01)$ after 3 months of treatment. In RA, rates of DAS28-CRP remission and low disease activity (LDA) were $29.6 \%$ and $22.2 \%$, respectively, and $65.2 \%$ of patients achieved good/moderate EULAR response. As for PsA, good/moderate EULAR response was observed in $78.8 \%$ of patients and $28 \%$ of patients achieved minimal disease activity. In axSpA, ASDAS-CRP $(p<0.01)$, BASDAI $(p<0.01)$ and ASAS-HI $(p=0.032)$ significantly reduced; rates of ASDAS-CRP inactive disease and LDA were $15.2 \%$ and $26.1 \%$, respectively; $14 \%$ of patients had a $\geq 50 \%$ improvement in baseline BASDAI. After 3 months of golimumab treatment, there was a decrease in the prevalence of enthesitis (32.9\% to $16.5 \%$ ), nail (17.6\% to $12.9 \%)$ and skin psoriasis (42.4\% to $34.1 \%$ ) in PsA patients; the frequency of extra articular manifestations tended to decrease also in axSpA patients.

Conclusion: Preliminary results of the GO-BEYOND-Italy study showed a good short-term effectiveness of golimumab in RA, PsA and axSpA after TNFi failure. 
Table 1. Effectiveness of golimumab at 3 months in the GO-BEYONDItaly study

\begin{tabular}{|c|c|c|c|c|c|}
\hline \multicolumn{2}{|l|}{$\begin{array}{l}\text { Rheumatoid arthritis } \\
(n=38)\end{array}$} & \multicolumn{2}{|c|}{$\begin{array}{l}\text { Psoriatic arthritis } \\
\qquad(n=91)\end{array}$} & \multicolumn{2}{|c|}{$\begin{array}{l}\text { Axial spondyloarthritis } \\
\qquad(n=64)\end{array}$} \\
\hline $\begin{array}{l}\text { DAS28-CRP, mean } \\
\text { (SD) }\end{array}$ & $n=27$ & $\begin{array}{l}\text { DAS28-CRP, } \\
\text { mean (SD) }\end{array}$ & $n=47$ & $\begin{array}{l}\text { ASDAS-CRP, } \\
\text { mean (SD) }\end{array}$ & $\mathrm{n}=44$ \\
\hline $\mathrm{V}_{0} / \mathrm{V} 1$ & $\begin{array}{l}4.05(0.8) / \\
3.10^{*}(1.0)\end{array}$ & V0/V1 & $\begin{array}{l}3.66(1.0) / \\
2.79^{*}(1.2)\end{array}$ & V0 / V1 & $\begin{array}{l}2.86(1.0) / \\
2.33^{*}(1.0)\end{array}$ \\
\hline $\begin{array}{l}\text { V1: DAS28-CRP } \\
\text { disease activity, } \\
\mathrm{n}(\%)\end{array}$ & $\mathrm{n}=27$ & $\begin{array}{l}\text { V1: EULAR } \\
\text { response, } \\
\text { n (\%) }\end{array}$ & $n=33$ & $\begin{array}{c}\text { V1: ASDAS-CRP } \\
\text { disease activity, } \\
n(\%)\end{array}$ & $\mathrm{n}=46$ \\
\hline Remission & $8(29.6)$ & Good & $16(48.5)$ & Inactive disease & $7(15.2)$ \\
\hline Low disease activity & $6(22.2)$ & Moderate & 10 (30.3) & Low disease activity & $12(26.1)$ \\
\hline $\begin{array}{l}\text { Moderate disease } \\
\text { activity }\end{array}$ & $13(48.1)$ & $\begin{array}{l}\text { No } \\
\text { response }\end{array}$ & $7(21.2)$ & $\begin{array}{c}\text { High disease } \\
\text { activity } \\
\text { Very high disease } \\
\text { activity }\end{array}$ & $\begin{array}{l}22(47.8) \\
5(10.9)\end{array}$ \\
\hline $\begin{array}{l}\text { V1: EULAR } \\
\quad \text { response, n (\%) }\end{array}$ & $n=23$ & $\begin{array}{c}\text { V1: MDA, } \\
\text { n (\%) }\end{array}$ & $\mathrm{n}=75$ & & \\
\hline Good & $7(30.4)$ & Yes & $21(28.0)$ & BASDAI, mean (SD) & $n=50$ \\
\hline Moderate & $8(34.8)$ & & & V0 / V1 & $\begin{array}{l}5.99(2.1) / \\
4.92(2.3)^{\star}\end{array}$ \\
\hline No response & $8(34.8)$ & & & $\begin{array}{c}\text { V1: BASDAI50, n (\%) } \\
\text { ASAS-HI, mean (SD) } \\
\text { V0 / V1 }\end{array}$ & $\begin{array}{c}7(14.0) \\
n=48 \\
10.67(3.8) / \\
9.68(4.6)^{\wedge}\end{array}$ \\
\hline
\end{tabular}

${ }^{*} \mathrm{p}$ value for the difference from $\mathrm{V} 0<0.01$. $^{\wedge} \mathrm{p}$ for the difference from $\mathrm{V} 0=0.032 \mathrm{Abbreviations}$ ASDAS: Ankylosing Spondylitis Disease Activity Score; ASAS-HI: Assessment of SpondyloArthritis international society Health Index; BASDAI: Bath Ankylosing Spondylitis Disease Activity Index; CRP: C-reactive protein; DAS: disease activity score; EULAR: European League Against Rheumatism; MDA: Minimal Disease Activity; SD: standard deviation; V0: baseline; V1: 3 months evaluation.

Disclosure of Interests: Salvatore DAngelo Speakers bureau: AbbVie, BMS, Celgene, Eli Lilly, Janssen, Merck, Novartis, Pfizer, UCB, Consultant of: AbbVie, BMS, Celgene, Eli Lilly, Janssen, Merck, Novartis, Pfizer, UCB, Enrico Tirri Speakers bureau: AbbVie, Eli Lilly, Novartis, Pfizer, Angela Maria Giardino Employee of: MSD Italia, Marco Matucci-Cerinic Speakers bureau: BMS, Pfizer, Actelion, Consultant of: Eli-Lilly, Celgene, Chemomab, CSL Behring, Grant/ research support from: BMS, Pfizer, Celgene, CSL Behring, Lorenzo Dagna Consultant of: Abbvie, Amgen, Biogen, Bristol-Myers Squibb, Celltrion, Novartis, Pfizer, Roche, Sanofi-Genzyme, and SOBI, Leonardo Santo: None declared., francesco ciccia: None declared., Bruno Frediani: None declared., Marcello Govoni: None declared., Francesca Bobbio Pallavicini: None declared., Rosa Daniela Grembiale: None declared., Andrea Delle Sedie: None declared., Stefania Cercone Employee of: MSD Italia, RITA MULE': None declared., Francesco Paolo Cantatore Speakers bureau: Pfizer, Sanofi Genzyme and Roche, Consultant of: Pfizer, Sanofi Genzyme and Roche outside this work., Rosario Foti: None declared., Elisa Gremese: None declared., Roberto Perricone: None declared., Fausto Salaffi: None declared., Ombretta Viapiana Speakers bureau: Novartis, UCB, Abbvie, MSD, Fresenius kabi, Gilead, Biogen, Consultant of: Novartis, Abbvie, Fresenius kabi, Gilead, Biogen, Alberto Cauli Speakers bureau: Abbvie, Alfa-Sigma, BMS, Celgene, Galapagos, Glaxo, MSD, Novartis, Janssen, Pfizer, Sanofi, UCB, Consultant of: Abbvie, Alfa-Sigma, BMS, Celgene, Galapagos, Glaxo, MSD, Novartis, Janssen, Pfizer, Sanofi, UCB, Rorberto Giacomelli: None declared., Luisa Arcarese: None declared., Giuliana Guggino Speakers bureau: Novartis, Celgene, Abbvie, Sandoz, Eli Lilly, Pfizer, Jansen, ROMUALDO RUSSO: None declared., Domenico Capocotta: None declared., Francesca Nacci: None declared., Maria Grazia Anelli: None declared., valentina picerno: None declared., Florenzo lannone Speakers bureau: Pfizer, AbbVie, Janssen, Celgene, Novartis, MSD, BMS, UCB, Roche, Consultant of: Pfizer, AbbVie, Janssen, Celgene, Novartis, MSD, BMS, UCB, Roche outside this work. DOI: 10.1136/annrheumdis-2021-eular.1518

\section{AB0468 $\quad$ IS THE USE OF INTERLEUKIN 17 INHIBITORS IN SPONDYLOARTHRITIS RELATED TO THE CLINICAL MANIFESTATIONS? 12-MONTH EXPERIENCE OF ONE RHEUMATOLOGY CENTER}

M. Khapsirokova ${ }^{1}$, Z. Kolkhidova ${ }^{1}, \underline{\text { S. Erdes }}{ }^{2} .{ }^{1}$ V. A. Nasonova Research Institute of Rheumatology, Moscow, Clinic, Moscow, Russian Federation; ${ }^{2}$ V. A. Nasonova Research Institute of Rheumatology, Moscow, Russia., Clinic, Moscow, Russian Federation

Background: Therapy with interleukin 17 (ilL17) inhibitors in Russia is indicated for patients with ankylosing spondylitis (AS) or psoriatic arthritis (PSA). If standard therapy is ineffective in these diseases, both tumor necrosis factor inhibitors (iTNF) and ilL17 can be prescribed as the first biologics.
Objectives: To study the clinical features of patients with spondyloarthritis (SPA) who were first prescribed ilL17 in a rheumatology center for 12 months.

Methods: During the period from January to December 2019, ilL17 was initiated to 43 SPA patients. To compare the clinical picture, the study additionally included 40 SPA patients who were prescribed iTNF during the same period. The diagnosis of AS was based on the $\mathrm{mNY}$ criteria, and psoriatic arthritis was based on the CASPAR criteria. In the combined group of 83 patients, AS was in $52(62.7 \%)$, and PSA - in 31 ; the age of patients was $39.3 \pm 10.8$ years, and the duration of the disease was $15.1 \pm 8.2$ years; men were $47(56.6 \%)$.

Results: In the ilL17 group, AS had 23 (53.5\%) patients, and PSA - 20 (46.5\%), while in the iTNF group, respectively, 29 (72.5\%) and 11 (27.5\%; $\chi 2=3.2, p=0.76)$ Among the patients who were prescribed ilL17, men were $29(67 \%)$, and in the iTNF group $-18(45 \% ; \chi 2=4.2, p=0.04)$. In terms of activity indicators (ESR, CRP, BASDAI ASDAS-CRP), patients who were prescribed ilL17 or ITNF did not differ significantly from each other. Peripheral arthritis, dactylitis, and entesitis were observed with almost the same frequency in both groups. In the ilL17 group, there were almost 2 times more patients with psoriasis $(53.5 \%$ and $25.0 \%$; $\mathrm{p}<0.05)$ than in group iTNF and among them, significantly more frequent the patients had previous experience of iTNF treatment $(41,9 \%$ and $17.5 \% ; p<0.05)$. Disease-modifying antirheumatic drugs often received patients in iTNF group (80.0\% and $48.8 \%$; $p<0.05)$.

Conclusion: Thus, in clinical practice ilL17 often prescribed for SPA male patients with psoriasis and previous treatment experience by iTNF. The activity of the disease and the presence of non-axial manifestations practically do not affect the choice of biological therapy.

Disclosure of Interests: None declared.

DOI: 10.1136/annrheumdis-2021-eular.1548

\section{$\mathrm{AB} 0469$ \\ PROTON PUMP INHIBITORS MAY IMPAIR RESPONSE TO TNF-INHIBITORS IN SPONDYLOARTHRITIS PATIENTS}

M. Masson ${ }^{1}$, M. Kostine ${ }^{1}$, T. Barnetche ${ }^{1}$, A. Saraux ${ }^{2}$, A. Ruyssen-Witrand ${ }^{3}$ T. Thomas ${ }^{4}$, D. Wendling ${ }^{5}$, M. E. Truchetet ${ }^{1}$, C. Richez ${ }^{1}$, T. Schaeverbeke ${ }^{1}$ ${ }^{1}$ Bordeaux University Hospital, Rheumatology, Bordeaux, France; ${ }^{2}$ Brest University Hospital, Rheumatology, Brest, France; ${ }^{3}$ Toulouse University Hospital, Rheumatology, Toulouse, France; ${ }^{4}$ Saint-Etienne University Hospital, Rheumatology, Saint-Etienne, France; ${ }^{5}$ Besançon University Hospital, Rheumatology, Besaonçon, France

Background: Considering the potential role of the gut microbiota in the pathophysiology of spondyloarthritis (SpA) as in the therapeutic response to biologics (1), we evaluated the hypothesis that co-medications known to interfere with the gut microbiota could impair the therapeutic response to TNF-inhibitors (TNF-i) in SpA patients. This was first suggested by the results of a retrospective cohort showing that a co-medication with proton pump inhibitors (PPIs), non-steroida anti-inflammatory drugs (NSAIDs) or antibiotics was significantly associated with a decreased chance to respond to a first TNF-I, independently of each other (2). Objectives: To validate in a replication cohort the potential negative association between therapeutic response to TNF-i and co-medication with commonly used drugs.

Methods: Demographic information and disease characteristics were retrospectively collected. Patients were classified as responder $(\mathrm{R})$ or non-responder (NR) according to the BASDAI $(<40 / 100)$ value at month 6 or to the clinician judgment (when BASDAI was not available). We collected all drugs known to interfere with the gut microbiota that were administered 1 month before and during the first 3 months of the TNF-i treatment. We only considered drugs given to more than $5 \%$ of patients. Univariate and multivariate analyses were performed to evaluate the relationship between co-medications, predictors of response known from literature and TNF-i response. All analyses were computed on STATA 13.1 with a statistically significant threshold of 0.05 .

Results: We included from 4 different centres 185 patients having axial SpA with radiographic or magnetic sacroiliitis in $75 \%$ and $73 \%$ of cases, respectively. One third of them had peripheral involvement. $73 \%$ were B27 positive. TNF-i administrated were infliximab $(8 \%)$, etanercept $(22 \%)$, adalimumab $(44 \%)$ golimumab (19\%), certolizumab $(7 \%) .127$ patients $(69 \%)$ were considered as R. $59.4 \%$ of patients who received NSAIDs were R, compared to $81 \%$ not treated with NSAIDs ( $\mathrm{p}<0.0001$ ). $43,3 \%$ of patients receiving PPIs were R compared to $83 \%$ of patients PPI free $(p<0.0001)$. Differences were not significant for antibiotics, methotrexate (MTX), psychotic drugs and corticosteroids. Considering known predictors of response, a magnetic sacroiliitis and the age at TNF-i initiation were significantly associated with a higher proportion of $R$ patients ( $p=0.048$ and 0.018 respectively). In multivariate analysis, PPIs intake remained associated with a poorer response to a first TNF-i $(p<0.001)$, even though $88 \%$ of patients exposed to PPIs received also NSAIDs. 